\title{
POSTĘPOWANIE TERAPEUTYCZNE W LECZENIU DOLEGLIWOŚCI BÓLOWYCH DOLNEJ CZĘŚCI PLECÓW - CZĘŚĆ III - PRZYKLADOWY PROGRAM TRENINGOWY
}

Therapeutic treatment for lower back pain treatment - Part III - Exemplary training program.

\section{Słowa kluczowe:}

program treningu kontroli

motorycznej, przykłady ćwiczeń.

\section{Key words:}

motor control training program, training examples.

\section{Streszczenie}

Trzecia czesść opracowania zawiera szczegółowy program rehabilitacji kontroli niekontrolowanego ruchu zgięcia odcinka lędźwiowego kręgosłupa z zastosowaniem koncepcji Kinetic Control. Opisano konkretne zadania ruchowe, ilość serii i powtórzeń oraz orientacyjny czas i częstotliwość treningu. Niektóre ćwiczenia oraz zalecenia można zastosować w terapii osób cierpiących na dolegliwości bólowe głównie dolnej cześsci pleców i nie tylko.

\section{Summary}

The third part of the study includes a detailed rehabilitation program for the control of uncontrolled spinal lumbar flexion movement using the Kinetic Control concept. Describes specific motion tasks, series and repetition scans, and an indicative time and frequency of training. Some exercises and recommendations can be used in the therapy of people suffering from pain mainly lower back and more.

Zaprezentowany poniżej przykładowy program, nazywany treningiem kontroli motorycznej, może być stosowany przed główną aktywnością fizyczną na poziomie początkującym oraz zaawansowanym/ mistrzowskim.

Program treningowy zawiera tylko nieliczne metody ruchowe, które stosuje się podczas rozgrzewki, która ma miejsce na początku treningu, a której celem jest rozgrzanie ciała, czyli podwyższenie jego temperatury, aby osoba mogła poczuć delikatne ciepło przed daną aktywnością fizyczną. Zaprezentowanie wszystkich pozycji i ruchów w trakcie treningu nie jest możliwe ze względu na to, że trening jest dopasowywany indywidualnie, zgodnie z potrzebami osoby go wykonującej, jej budową anatomiczną, możliwościami, wytrenowaniem.

Do pełnego, a nawet częściowego uzyskania prawidłowej biomechaniki kompleksu lędźwiowo-miednicznego potrzebny jest czas. Konsekwentne podejście do poniższych zadań ruchowych umożliwia osiągnięcie upragnionych rezultatów. Zaleca się je stosować przed częścią główną treningu niezależnie od jego rodzaju. Mogą one być wykorzystywane przed treningiem charakterystycznym dla sportów sylwetkowych, przed treningiem do sztuk walki, przed bieganiem, kolarstwem, a nawet przed zajęciami fitness, czy też przed gimnastyką w warunkach domowych itp. Pokazane poniżej ćwiczenia mają na celu przygotować ciało i umysł ćwiczącego do dalszego treningu. Dzięki zapamiętaniu wzorców utrzymania właściwej pozycji ciała oraz odpowiedniemu pobudzeniu aparatu ruchu wpływa sie korzystnie na układ nerwowy oraz zmniejsza się ryzyko wystąpienia kontuzji.

Ćwiczenie 1. Ćwiczenie rozciągające głównie mięśnie zginacze miednicy, przedstawione $\mathrm{w}$ trzech pozycjach (A,B,C) przy ustalonej miednicy. Pierwsza pozycja w klęku umożliwia ustalenie kompleksu lędźwiowo-miednicznego w prawidłowej pozycji - należy wciągnać brzuch i maksymalnie ścisnacć pośladki oraz ustawić miednicę bardziej w tyłopochyleniu. Pozycję A należy trzymać przez 30 sekund.

Następnie ćwiczący przechodzi do klęku na jedną nogę, trzymając cały czas wywołane wcześniej napięcie mięśni 


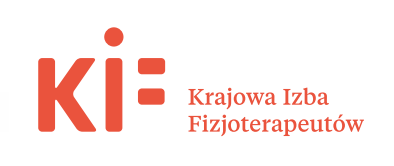

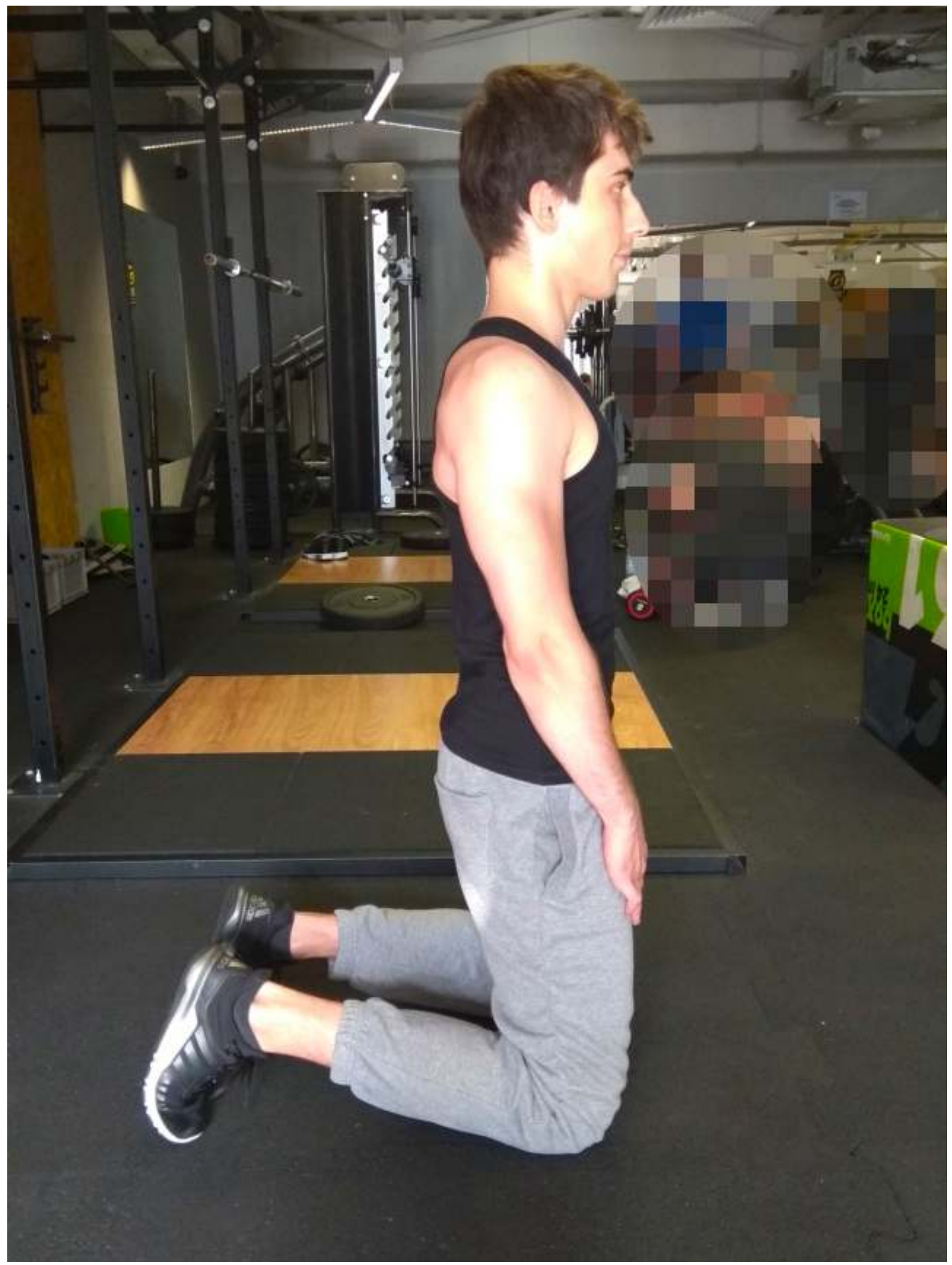

Fot.1. Pozycja A ćwiczenia 1 (archiwum własne, 2018) 


$$
12
$$

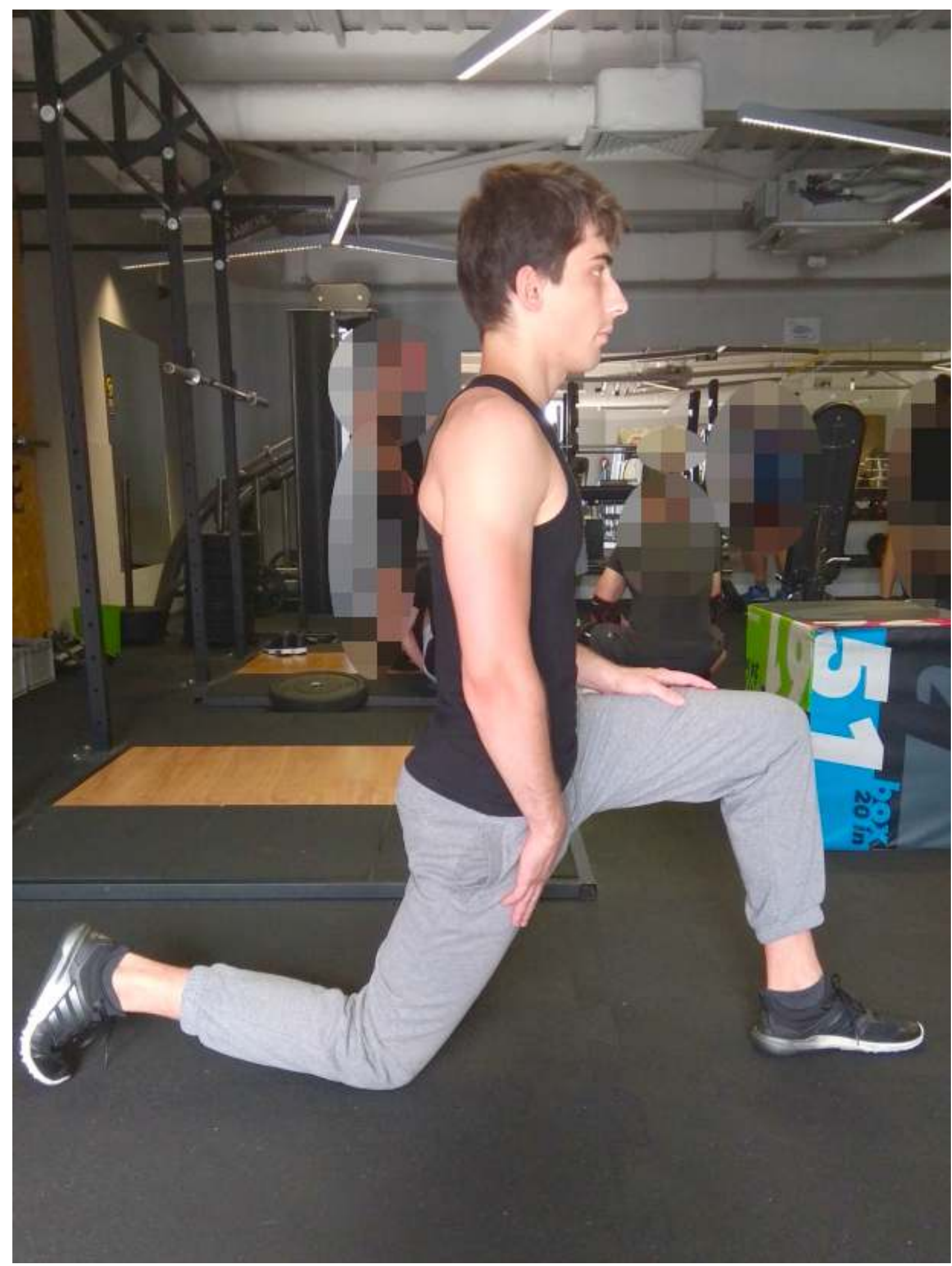

Fot.2. Pozycja B ćwiczenia 1 (archiwum własne, 2018) 

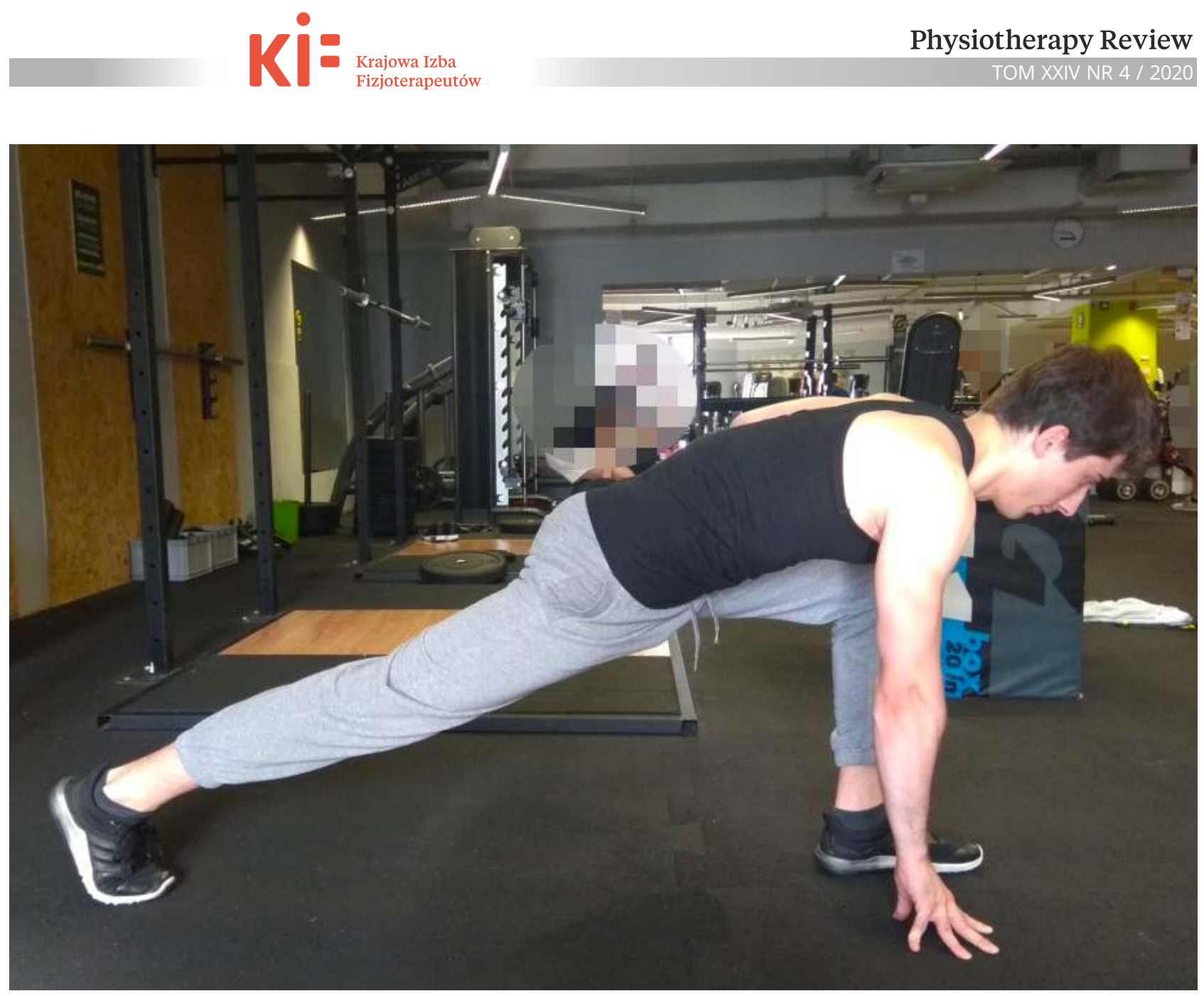

Fot.3. Pozycja C ćwiczenia 1 (archiwum własne autorki, 2018)

brzucha i pośladków oraz właściwe ustawienie bioder. Podczas pozycji B ćwiczący opuszcza biodro w kierunku podłoża na tyle, na ile jest w stanie utrzymać ustaloną pozycję miednicy w trakcie ruchu. Należy pamiętać o oddychaniu i wraz z wydechem zwiększać regularnie (tj. z dnia na dzień, a nie z sekundy na sekundę) możliwości ruchowe w stawie biodrowym. Przyjętą pozycję należy trzymaj 30 sekund do 1 minuty.

Następnie ćwiczący przechodzi do pozycji C. Należy wyprostować staw kolanowy nogi tylnej, opuszczając cały czas biodro w dół w zależności od aktualnych możliwości oraz trzymać noge z przodu tak, aby udo i podudzie nogi przedniej tworzyły kąt prosty. Pozycję końcowa (jak na fot. 3) należy przytrzymać do 1 minuty i powtórzyć to samo na drugą nogę.
Ćwiczenie 2. Służy rozluźnieniu mięśnia gruszkowatego (fot.4) oraz mięśni bocznej części uda (fot.5) za pomocą piłeczki oraz roller'a.

Pomocne jest utrzymanie prawidłowej postawy ciała w szczególności miednicy podczas rolowania w pozycji bocznej. Przed przystąpieniem do ćwiczenia należy wciągnać brzuch, ścisnać pośladki i ustawić właściwą pozycję miednicy. Kolejne zadania ruchowe należy wykonywać powoli i z wyczuciem. Najpierw należy głęboko położyć się/usiąść na przybór, aby umożliwić głębokie rozluźnienie. Na początku można poczuć lekki dyskomfort, nie mniej jednak należy przyjętą pozycję przytrzymać parę sekund dopóki ciało wstępnie się przyzwyczai. Następnie zaczyna się „masować” od góry do dołu kończynę dolną, trzymając dłużej w miejscach największego dyskomfortu.
Nigdy nie należy się cofać - zjeżdżając stopniowo w dół należy dojść do stawu kolanowego i dopiero wrócić wałkiem do góry. W trakcie wykonywanego rolowania należy omijać wyrośla kostne.

W przypadku rozluźniania pośladka z użyciem piłeczki można „masować” na boki. Rolowanie piłeczką trwa od 1 minuty nawet do 3-5 minut w zależności od indywidualnego zapotrzebowania i problemu. Wałkiem zaleca się wykonanie 15-20 ruchów, przy czym ruch od góry do dołu i z powrotem liczony jest jako jeden ruch lub rolowanie boku uda przez około 1-2 minuty.

Ćwiczenie 3. Służy do aktywacji mięśnia poprzecznego brzucha. Zaczyna się ono od zlokalizowania tego mięśnia (fot. 6) w okolicy pachwin i kolców biodrowych przednich górnych oraz na wyczuciu delikatnego skurczu pod 
opuszkami palców w trakcie wydechu i próby przybliżenia spojenia łonowego do pępka. Należy w tym miejscu pamiętać, że u każdego można w różny sposób wyczuć skurcz tych mięśni. Zazwyczaj można zlokalizować mięsień poprzeczny brzucha w okolicy kolców biodrowych przednich górnych. Należy zwrócić uwage na to, że jest to mięsień zaliczany do grupy mięśni głębokich, stabilizujących, czyli w dużej mierze wpływa na „przytrzymanie” od środka zawartości jamy brzusznej. Im lepsza kondycja mięśnia poprzecznego brzucha, tym bardziej przekłada się na wygląd sylwetki. Prawidłowe opracowywanie tego mięśnia wpływa też na uzyskanie płaskiego i jędrnego brzucha.

Ćwiczenie zaczyna się od wznosu w przód (fot. 7) , a następnie przechodzi się do delikatnego skrętu do boku na tyle, aby utrzymać nieruchomo pozycję ramion i barków oraz właściwą ustaloną pozycję miednicy (fot. 8). Na początek wykonuje się do 8 powtórzeń na stronę, a wraz z progresją umiejętności można zwiększyć do 15-20 powtórzeń. Liczba powtórzeń to 1-2 serie, a dochodzac do 4-5 serii można traktować to już jako ćwiczenie do części głównej treningu na mięśnie brzucha.

Ćwiczenie 4. Służy do aktywizacji mięśnia wielodzielnego. Polega na wyczuciu delikatnego skurczu mięśnia pod opuszkami palców między kręgosłupem, a prostownikami grzbietu. Ćwiczący przyjmuje pozycję taką, jak na fot.9 i podejmuje próbę przybliżenia wierzchołka kości krzyżowej do wyrostków kolczystych kręgów lędźwiowych. Fot. 10 pokazuję ułożenie palców dłoni do ćwiczenia.

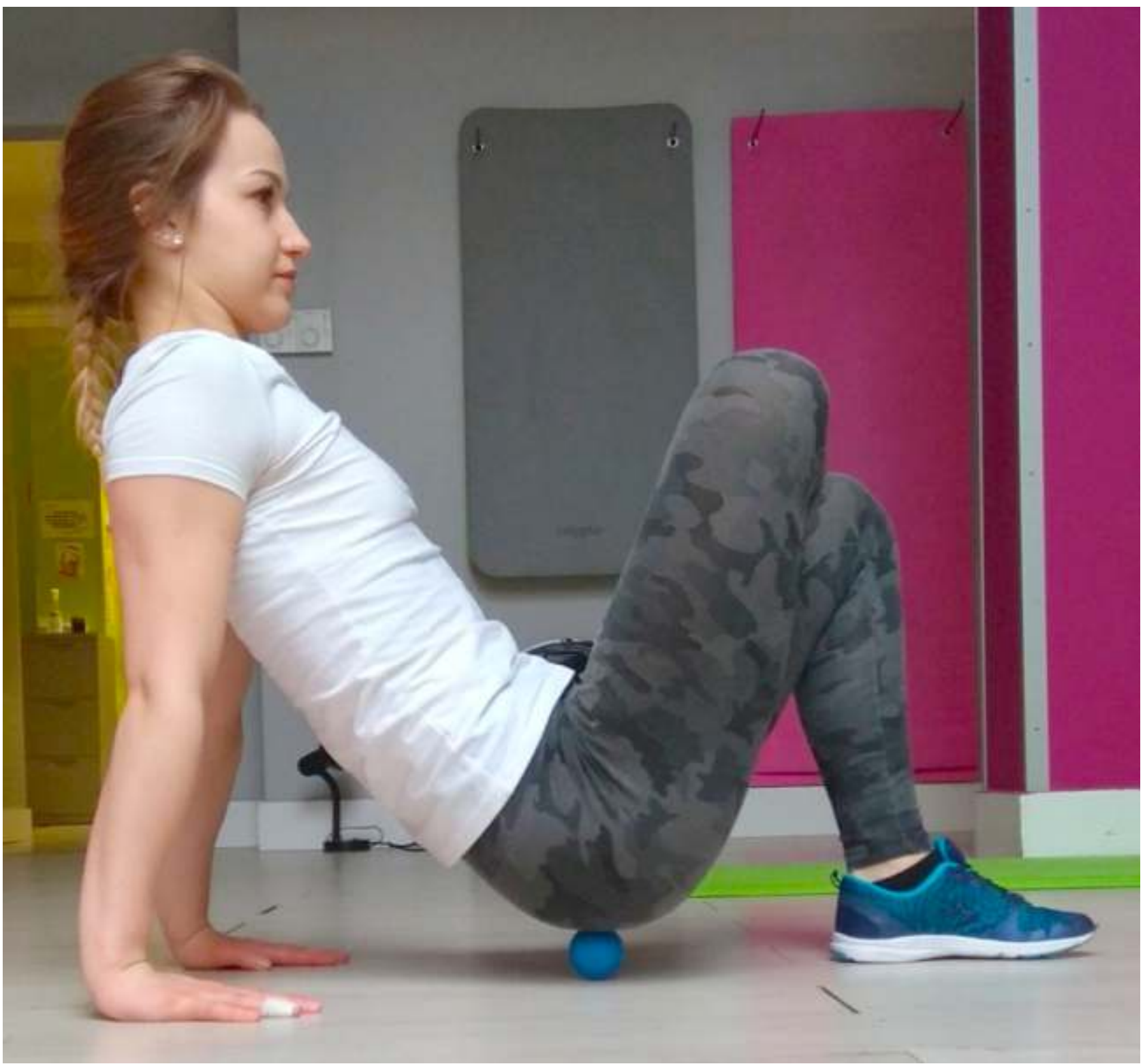

Fot. 4. Rozluźnienie mięśnia gruszkowatego za pomocą piłeczki (archiwum własne, 2018) 


$$
12
$$

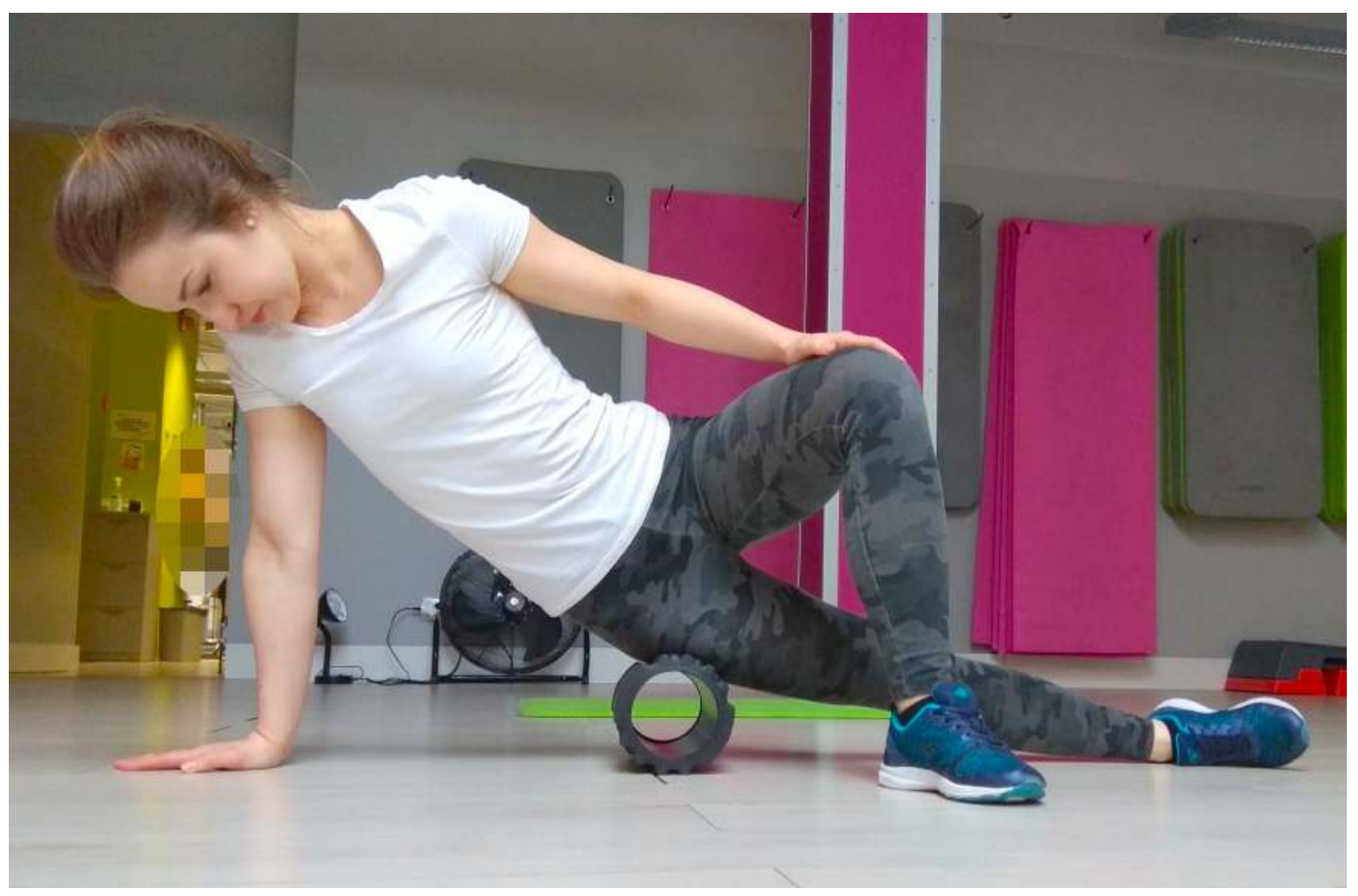

Fot. 5. Rozluźnienie mięśni bocznej części uda za pomocą roller’a (archiwum własne, 2018)

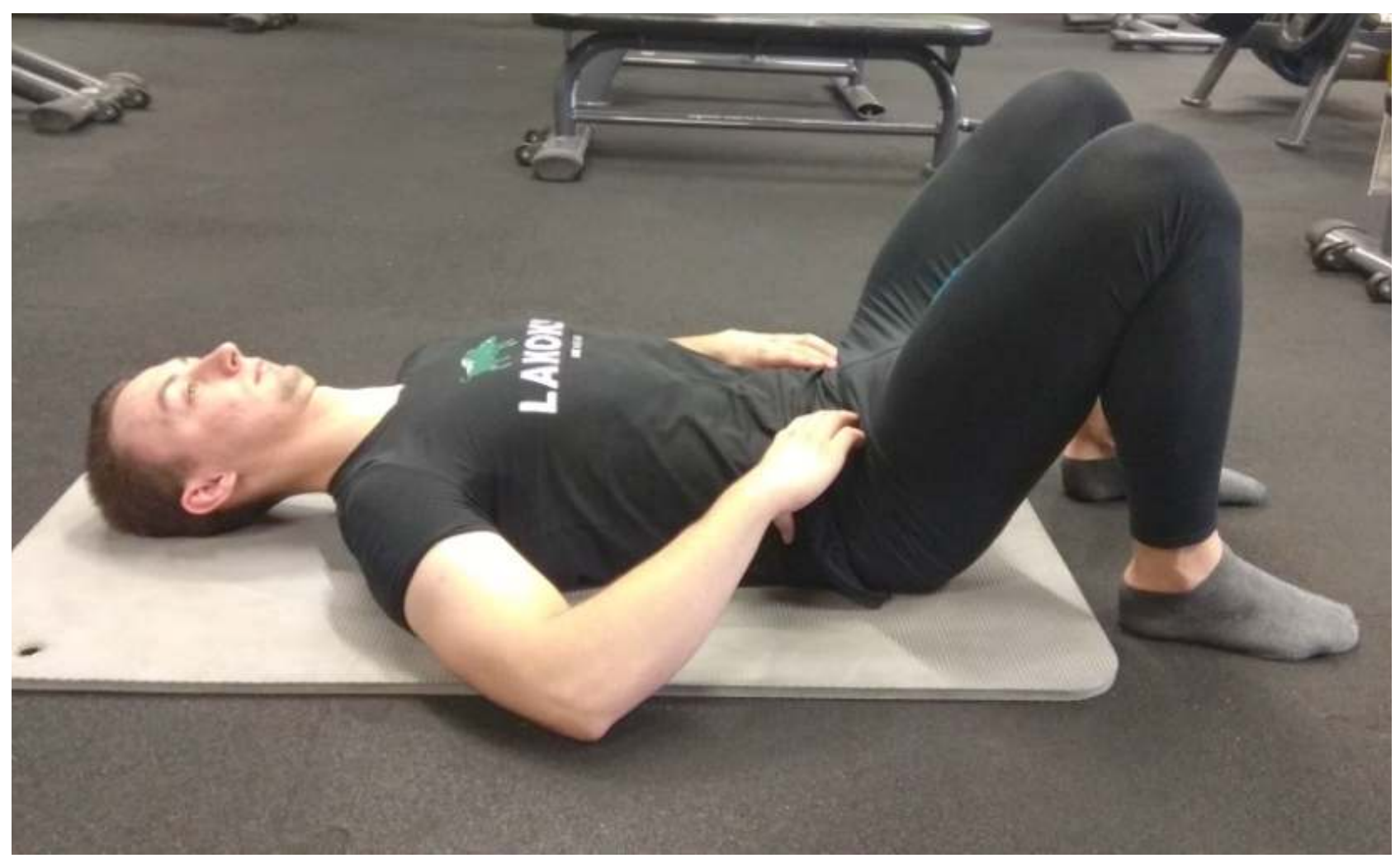

Fot. 6. Lokalizacja mięśnia poprzecznego brzucha (archiwum własne, 2018)

www.kif.info.pl 


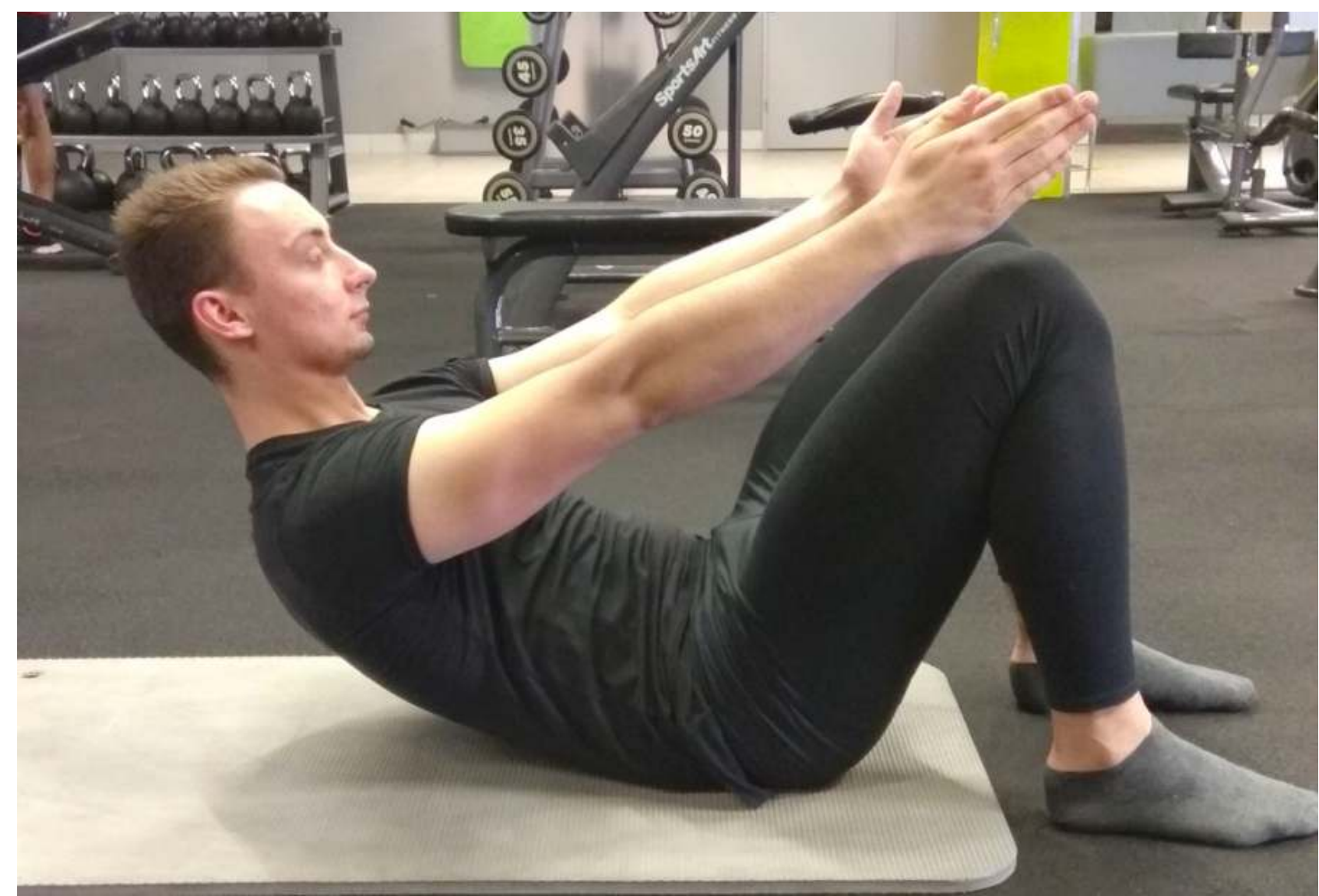

\section{Fot. 7. Wznos w przód (archiwum własne, 2018)}

Ćwiczenie 5. Poniżej zostały przedstawione pozycje ruchowe na mięśnie brzucha $\mathrm{z}$ wykorzystaniem własnego ciężaru ciała rycina (fot.11) oraz przy użyciu przyrządów (fot.12).

Bardzo ważnym jest aby przed przystąpieniem do zadania ustawić miednicę w prawidłowej i napiętej pozycji, czyli brzuch wciągnięty i lekko ściśnięte pośladki. W trakcie unoszenia tułowia nad podłogą maksymalnie należy wcisnąć całą stopę w podłoże i jeszcze bardziej napiąć mięśnie brzucha, „zasysając” pępek w kierunku kręgosłupa. Wykonuje się od 8 do 15 powtórzeń po 2 do 4 serii w zależności od kondycji mięśni brzucha oraz od utrzymania odpowiedniej postawy.

Jeżeli to ćwiczenie jest już dobrze opanowane można przejść do następnego ruchu przy użyciu bosu, bądź piłki. Metodyka w tym ćwiczeniu jest taka sama, jak w ćwiczeniu $\mathrm{z}$ własnym ciężarem ciała. Najważniejsze są utrzymanie prawidłowej postawy ciała oraz wykonywanie takiego zakresu ruchu i takiej ilości powtórzeń oraz serii, na ile ćwiczący jest w stanie dopilnować techniki.

Ćwiczenie 6. Służy do opracowania mięśni skośnych brzucha. Ważnym jest dopilnowanie utrzymania prawidłowej postawy miednicy podczas ruchu, czyli trzymania przez ćwiczącego w jednej linii i na jednym poziomie obu kolców biodrowych przednich górnych. Zaczyna się od uniesienia łopatki nad podłogę, a następnie przechodzi się do lekkiego skrętu tułowia, dłonią wyciągniętej ręki podążając do przeciwległego kolana. Najlepiej wykonywać 8-20 powtórzeń na każdą stronę. Sugestia ta dotyczy również ilości wykonywanych serii.

Ćwiczenie 7. Jest propozycją ćwiczenia na mięśnie pośladkowe. Pierwszą pozycję można także wykonywać przy użyciu gumy nad kolana pod warunkiem, że ćwiczenie $\mathrm{z}$ własnym ciężarem ciała wykonywane jest bezbłędnie. Dodatkowy opór będzie progresją postępowania treningowego. Jeśli przy zadaniu ruchowym z własnym ciężarem ciała (fot.14) ćwiczący czuje pośladki i trzyma neutralną lordozę lędźwiową, można przejść do bardziej zaawansowanych ćwiczeń przy użyciu gumy (fot.15), albo sztangi (fot.16).

Ćwiczenie z obciążeniem zewnętrznym wzmacnia mięśnie pośladkowe oraz wymusza ustawienie miednicy w neutralny sposób. Polega na silnym ściśnięciu pośladków w trakcie unoszenia miednicy z oparciem kreggosłupa piersiowego o ławeczkę lub w pozycji leżącej na plecach. Zwiększając obciążenie, należy zredukować ilość powtórzeń, np. jeśli zastosuje się w czterech kolejnych seriach obciążenie $20 \mathrm{~kg}, 40 \mathrm{~kg}, 50 \mathrm{~kg}$ i $60 \mathrm{~kg}$, to ilość powtórzeń wynosi 20, 15, 10 i 5 ruchów. Należy wykonać od 5-10 do 20 powtórzeń, maksymalnie od 2 do 4 serii 


$$
\text { Krajowa Izba }
$$

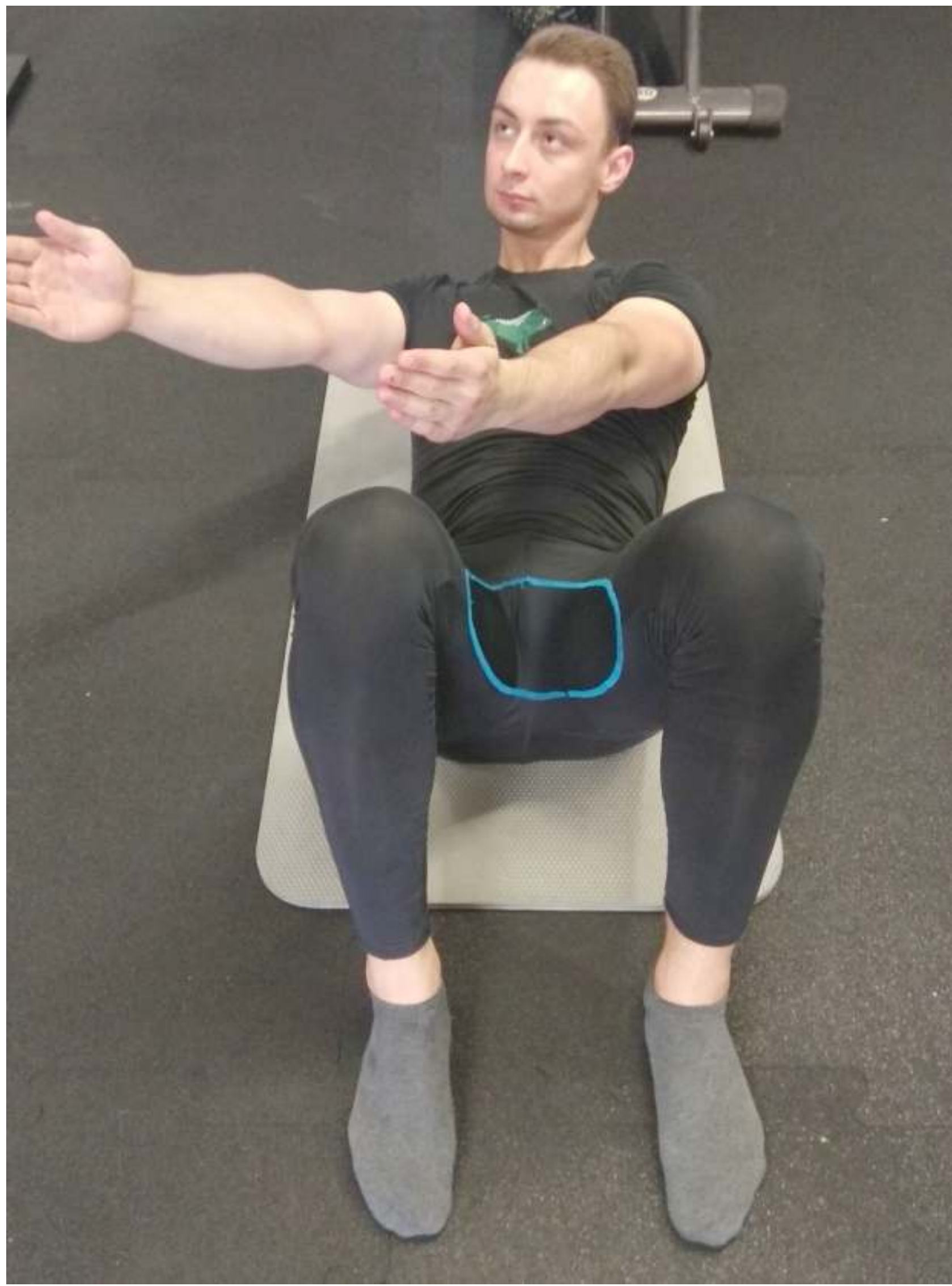

Fot. 8. Delikatny skręt do boku (archiwum własne, 2018)

www.kif.info.pl 


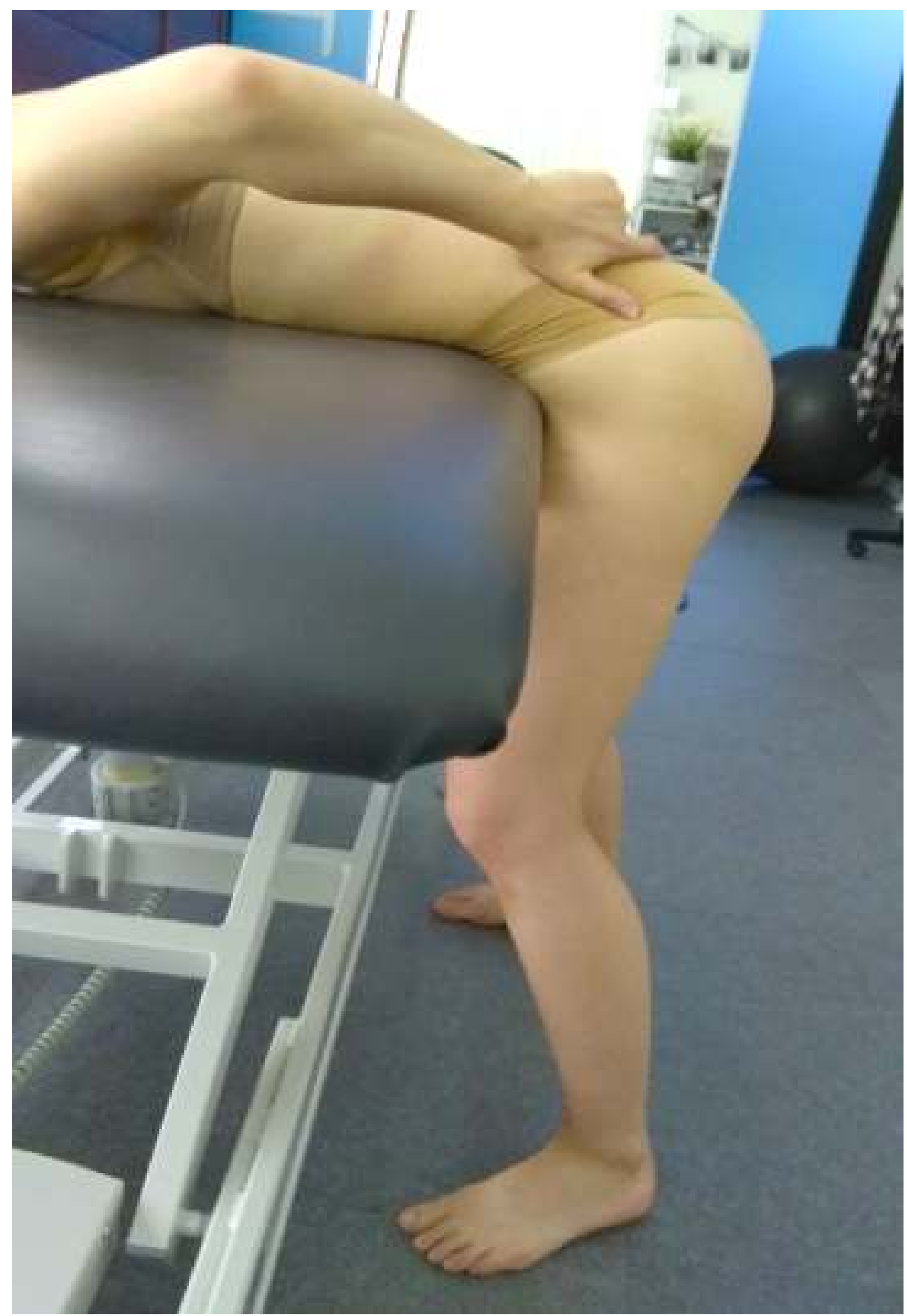

Fot. 9. Pozycja do ćwiczenia 4 (archiwum własne, 2018) 


$$
\text { Krajowa Izba }
$$

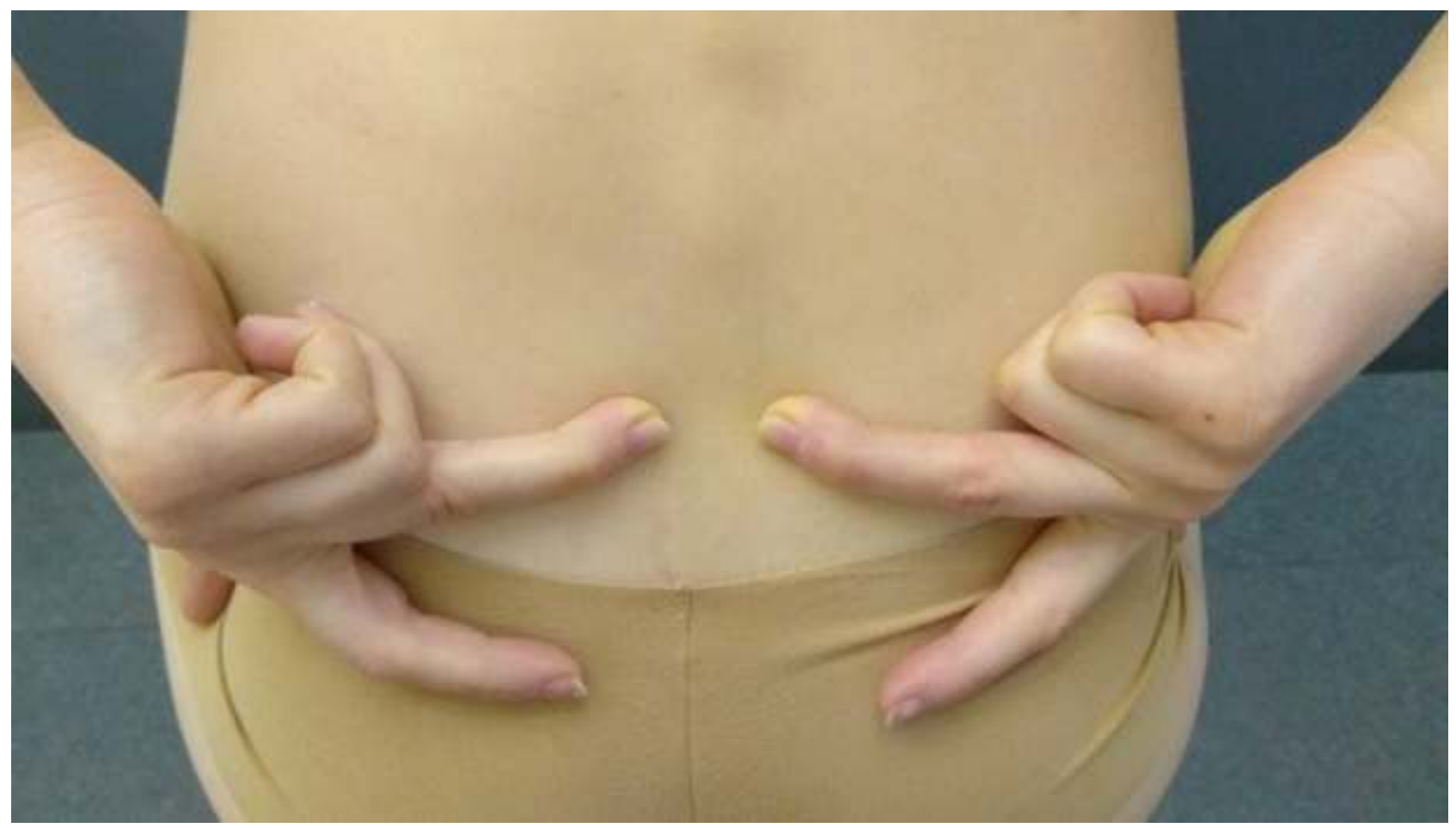

Fot. 10. Ułożenie palców dłoni do ćwiczenia 4 (archiwum własne, 2018)

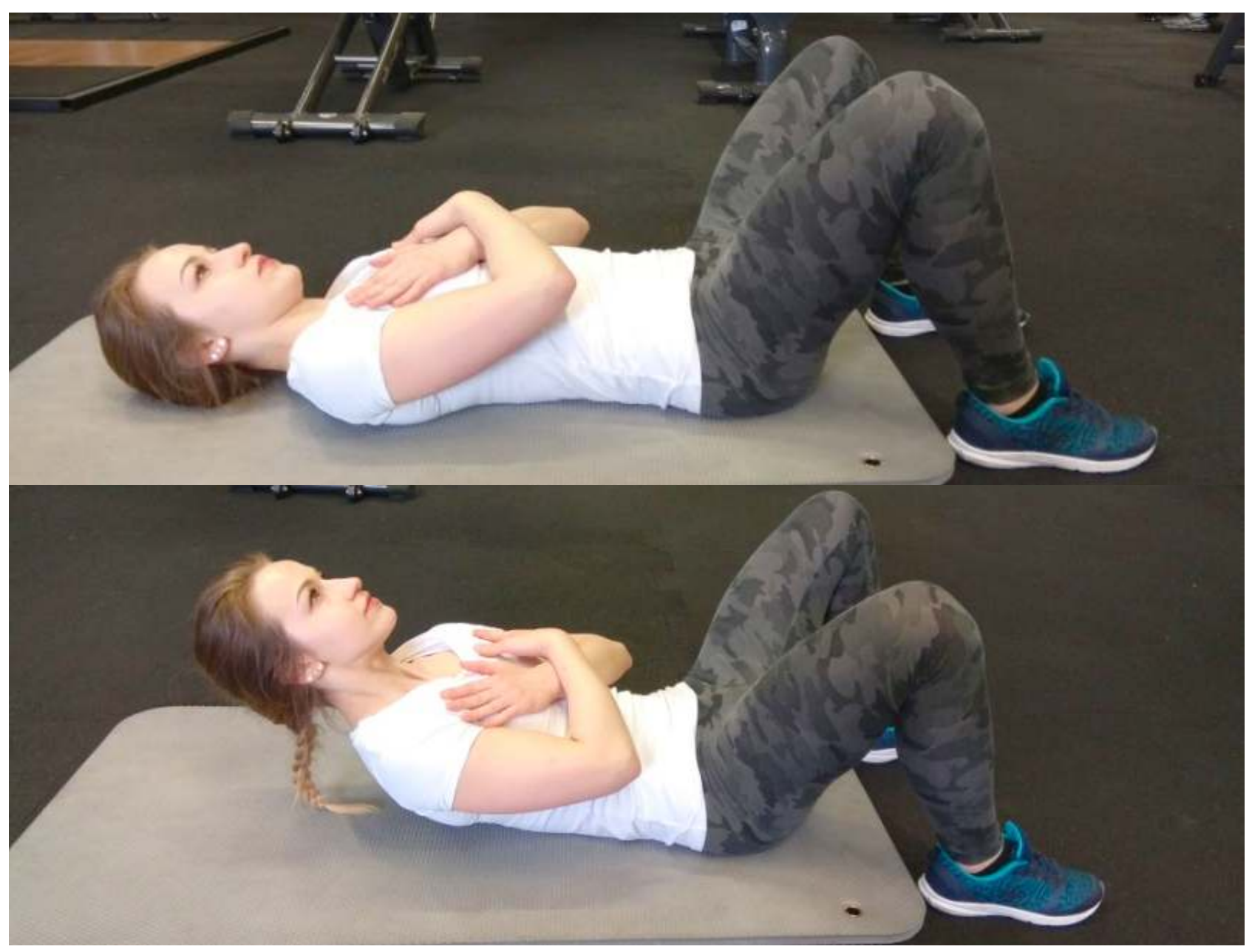

Fot. 11. Pozycje ruchowe na mięśnie brzucha $z$ wykorzystaniem własnego ciężaru ciała (archiwum własne, 2018)

www.kif.info.pl 


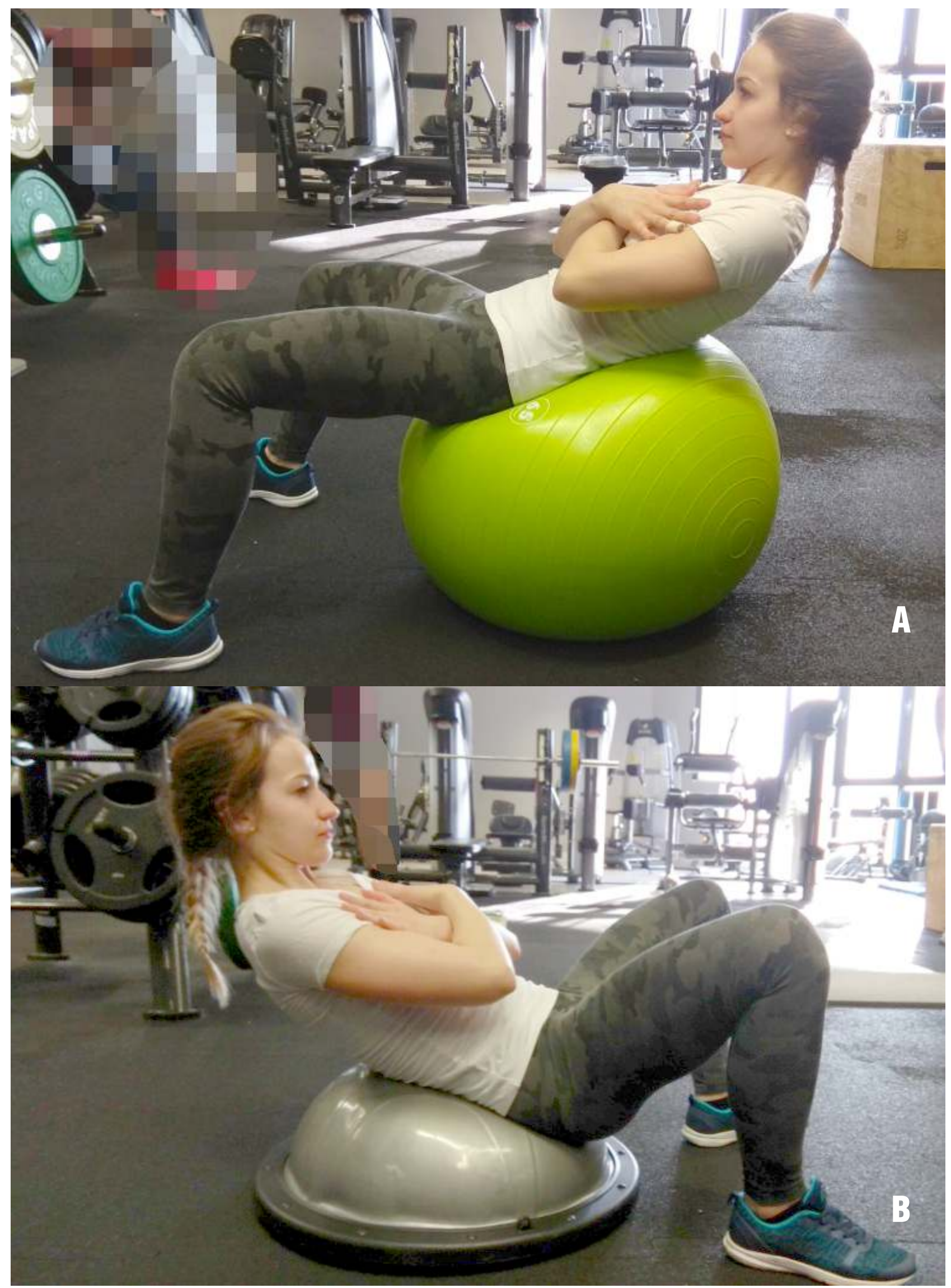

Fot. 12. Pozycje ruchowe na mięśnie brzucha z wykorzystaniem przyrządów A) piłka B) bos (archiwum własne, 2018) 


$$
170 \text { Krajowa Izba }
$$
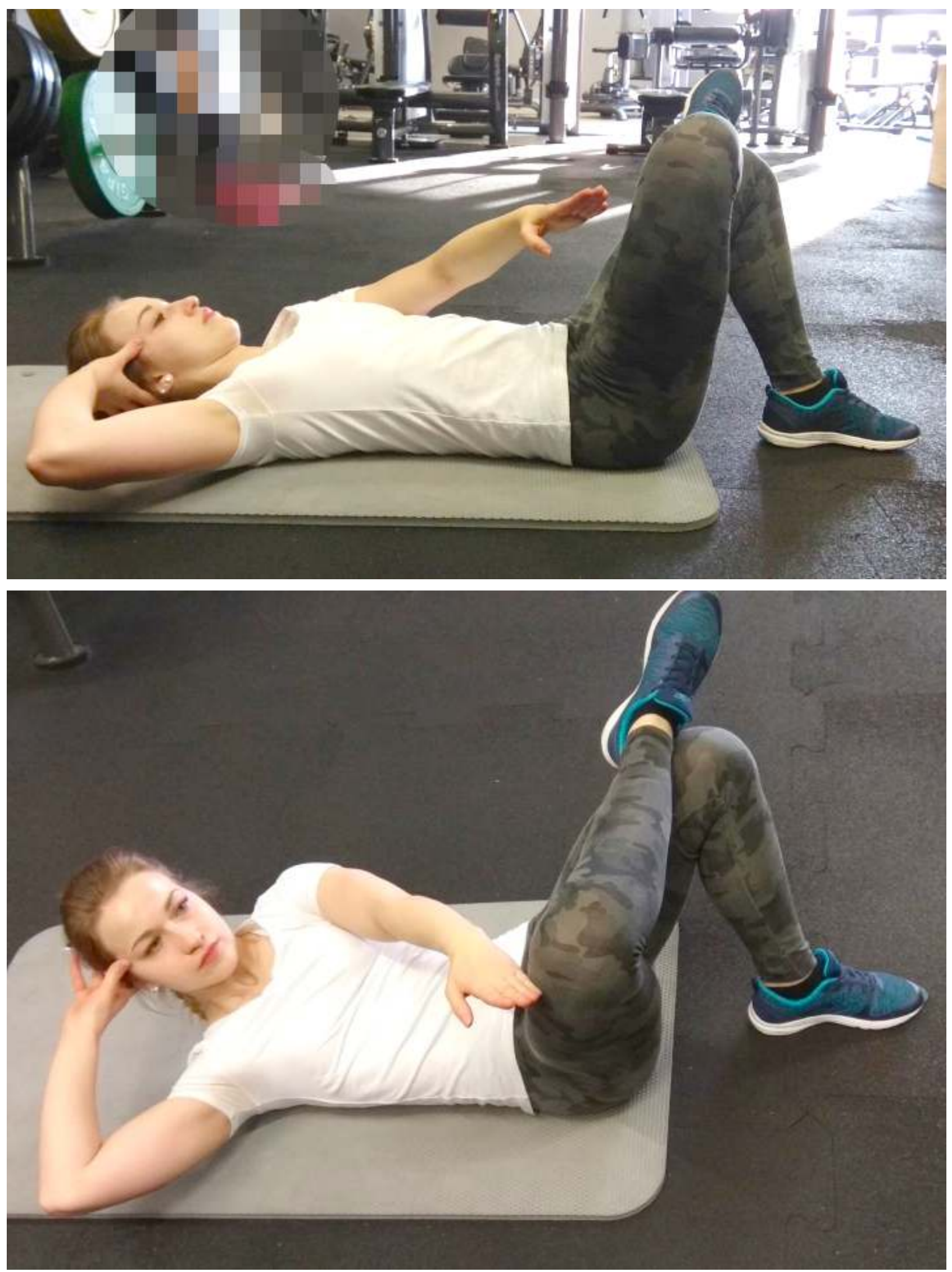

Fot. 13. Technika wykonania ćwiczenia 6 (archiwum własne, 2018)

www.kif.info.pl 

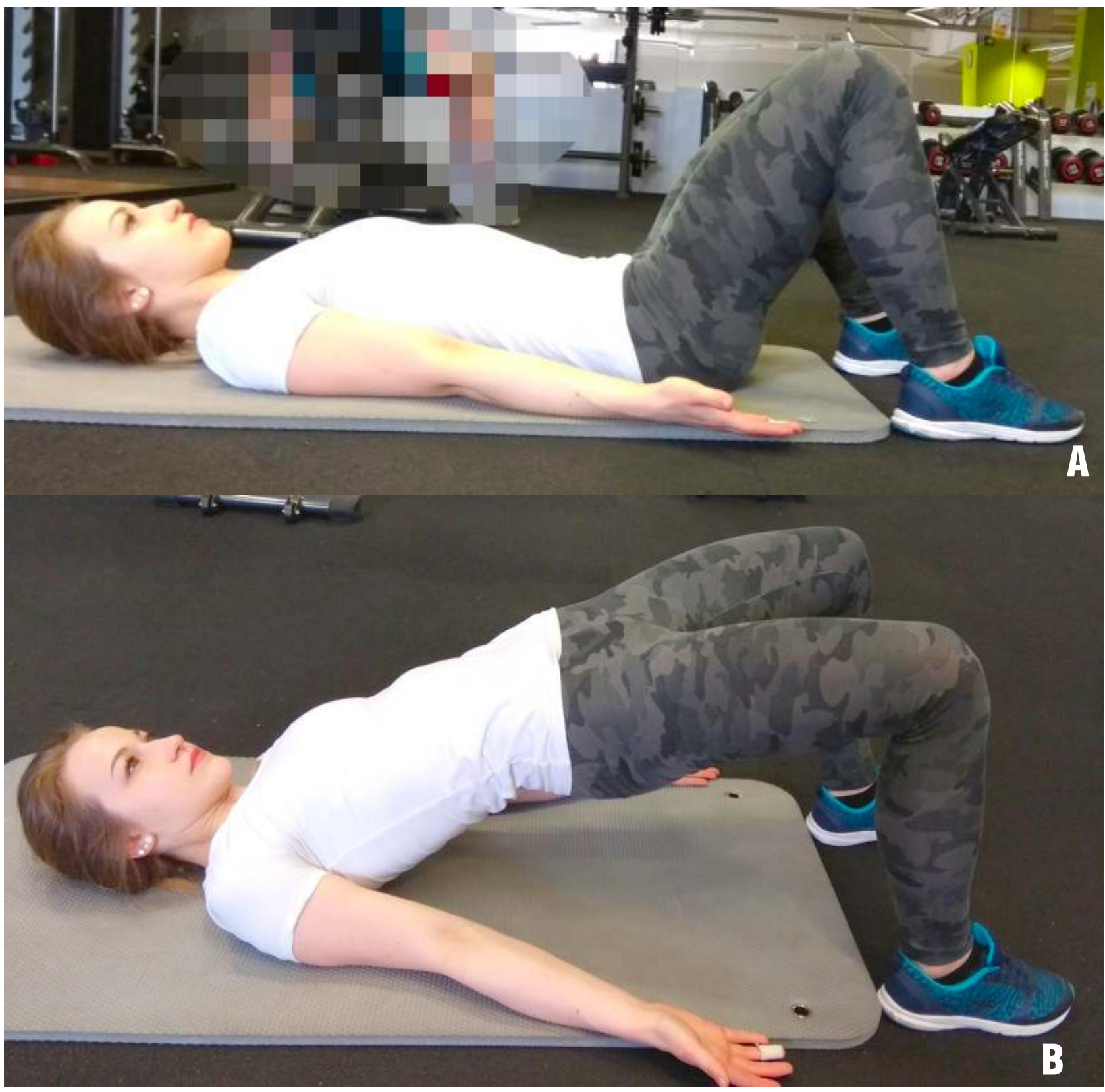

Fot. 14. Technika wykonania ćwiczenia 7 z wykorzystaniem własnego ciężaru ciała (archiwum własne, 2018)

bez względu na to, co do wykonania tego ćwiczenia jest użyte.

Ćwiczenie 8. Ćwicząc należy pamiętać, aby zachować równowagę, czyli jeżeli wzmacnia się mięśnie, to także powinno się dbać o ich rozciaganie i rozluźnianie. Zamieszczona poniżej fotografia pokazuje ćwiczenie na rozciąganie głównie mięśni pośladkowych i mięśnia gruszkowatego.

W trakcie tego ćwiczenia należy trzymać przednią nogę pod kątem prostym i opuszczać przeciwległe biodro w dół w zależności od aktualnych możliwości ćwiczącego. Dla osób rozciągniętych można dodać dociśnięcie przedramienia po stronie dociskającego biodra. Na przykład jeśli prawa noga ćwiczącego jest z przodu to opuszcza on lewe biodro na tyle, na ile jest w stanie. Jeżeli ćwiczący jest osobą rozciągniętą, to jej biodra będa bardzo nisko nad podłogą, jak na zamieszczonych fotografiach. Pozycję ćwiczeniową należy trzymać około 1 minuty na stronę.
Ćwiczenie 9. Jest to ćwiczenie rozciągające mięsień biodrowo-lędźwiowy oraz innych mięśni, które w dużej mierze odpowiadają za zgięcie stawu biodrowego. Przedstawione ustawienie pomaga na głębokie i dokładne rozciągnięcie mięśni zginaczy miednicy.

Podczas zaproponowanego ćwiczenia należy trzymać naprężony pośladek (pośladek musi być ściśnięty). Kolano tylnej nogi maksymalnie należy przybliżyć do ściany, aby część ciała bezpośrednio stykała 


$\begin{array}{rr}\text { Krajowa Izba } & \text { Physiotherapy Review } \\ \text { Fizjoterapeutów } & \text { TOM XXIV NR 4/ } 2020\end{array}$
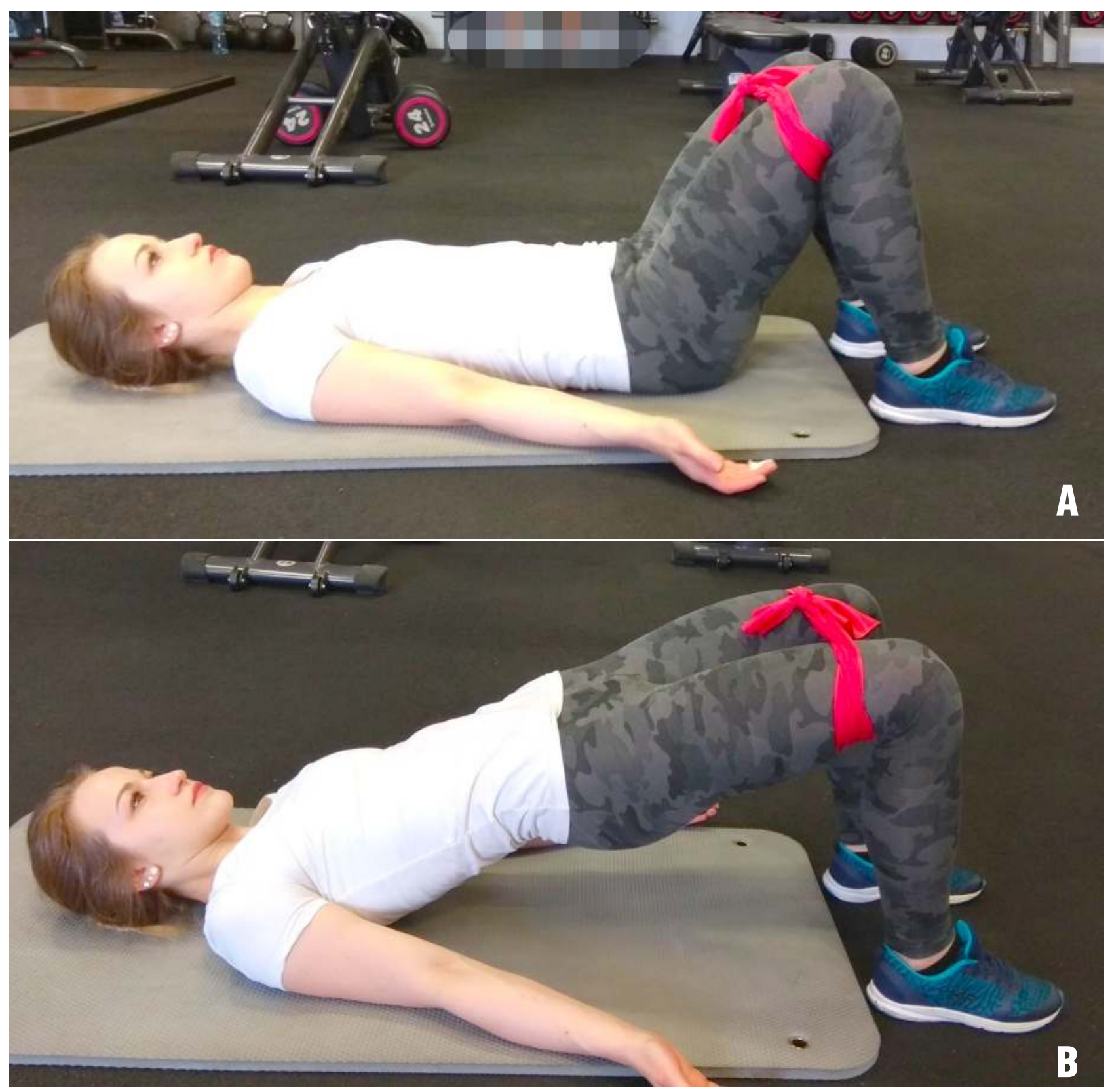

Fot. 15. Technika wykonania ćwiczenia 7 z wykorzystaniem gumy (archiwum własne, 2018)

się z przedmiotem. Jest to zadanie ruchowe zalecane dla osób, które posiadają już pewny poziom rozciągnięcia. Ćwiczenie należy wykonywać na tyle, na ile pozwala ciało ćwiczącego, aktualny jego stan zdrowia i obecne umiejętności. Pozycję ćwiczeniową należy trzymaj około 1 minuty na stronę. Dla osób początkujących ćwiczenie to przyjmuje wersję opisaną w ćwiczeniu 1.

Ćwiczenie 10. Dedykowane jest wzmacnianiu zginaczy miednicy. Jest to bardzo ważne, ponieważ grupa tych mięśni odpowiada za biomechanikę stawu biodrowego, kontroluje także ułożenie głowy kości udowej w trakcie zgięcia. Do grupy zginaczy stawu biodrowego zalicza się m.in. mięsień biodrowo-lędźwiowy (także stabilizuje kręgosłup lędźwiowy i jest odpowiedzialny za utrzymanie lordozy lędźwiowej), mięsień prosty uda, naprężacz powięzi szerokiej, jak również mięsień krawiecki, smukły i przywodziciel wielki (wspomagają ruch zgięcia stawu biodrowego). Posiadanie przynajmniej optymalnej wydolności wymienionych mięśni jest gwarancją lepszej sprawności. Prawidłowa biomechanika stawu biodrowego umożliwia lepsze poruszanie się, ponieważ jest to jeden z głównych stawów w ciele człowieka, który przyjmuje największe obciążenia i może wygenerować największą siłę. Dlatego bardzo istotne jest dbanie również o wzmacnianie mięśni zginających miednice. Zaproponowane ćwiczenie to jedna $\mathrm{z}$ wielu propozycji na 

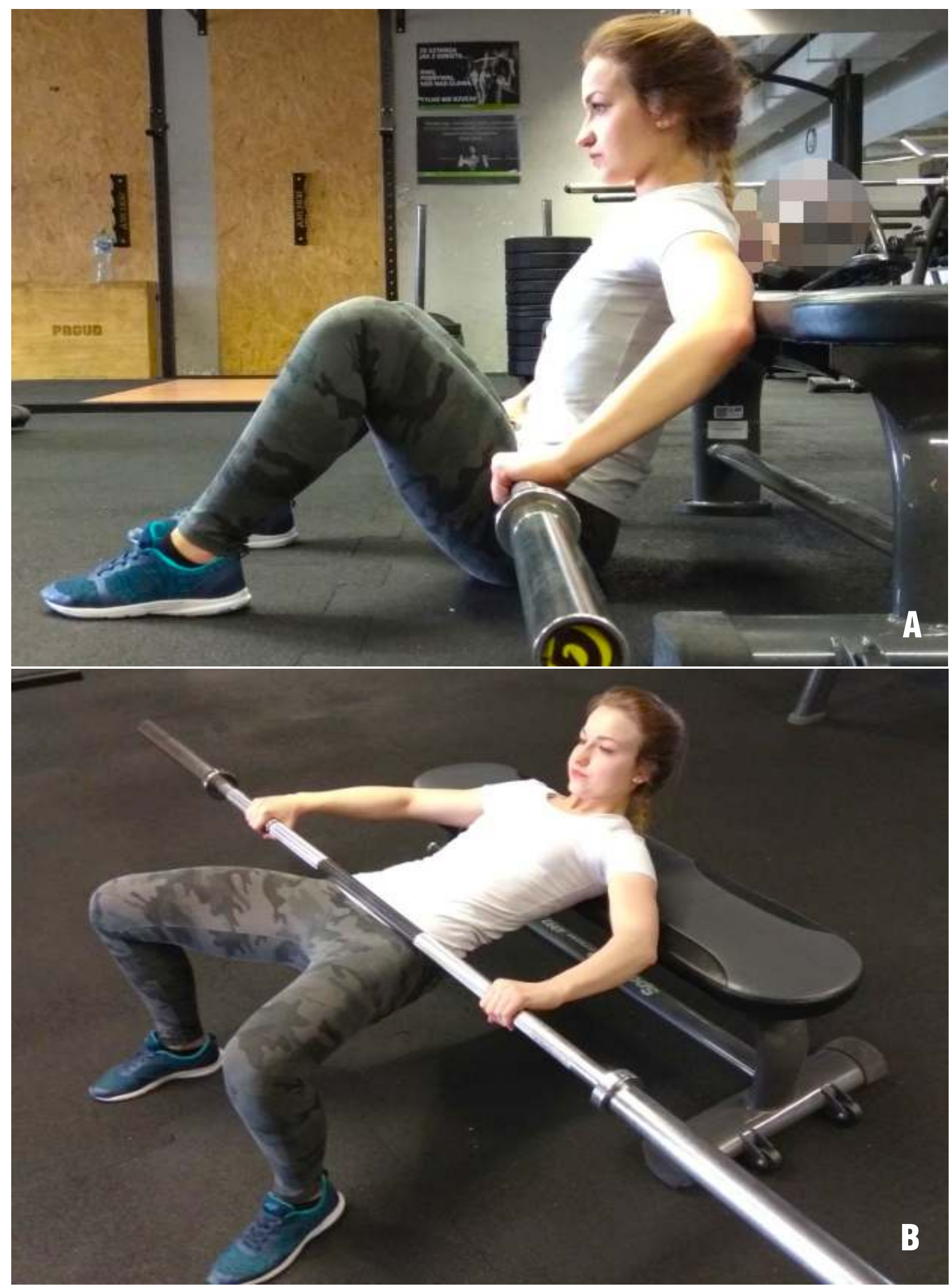

Fot. 16. Technika wykonania ćwiczenia 7 z wykorzystaniem sztangi (archiwum własne, 2018) 


$$
\mathrm{Ki}=
$$
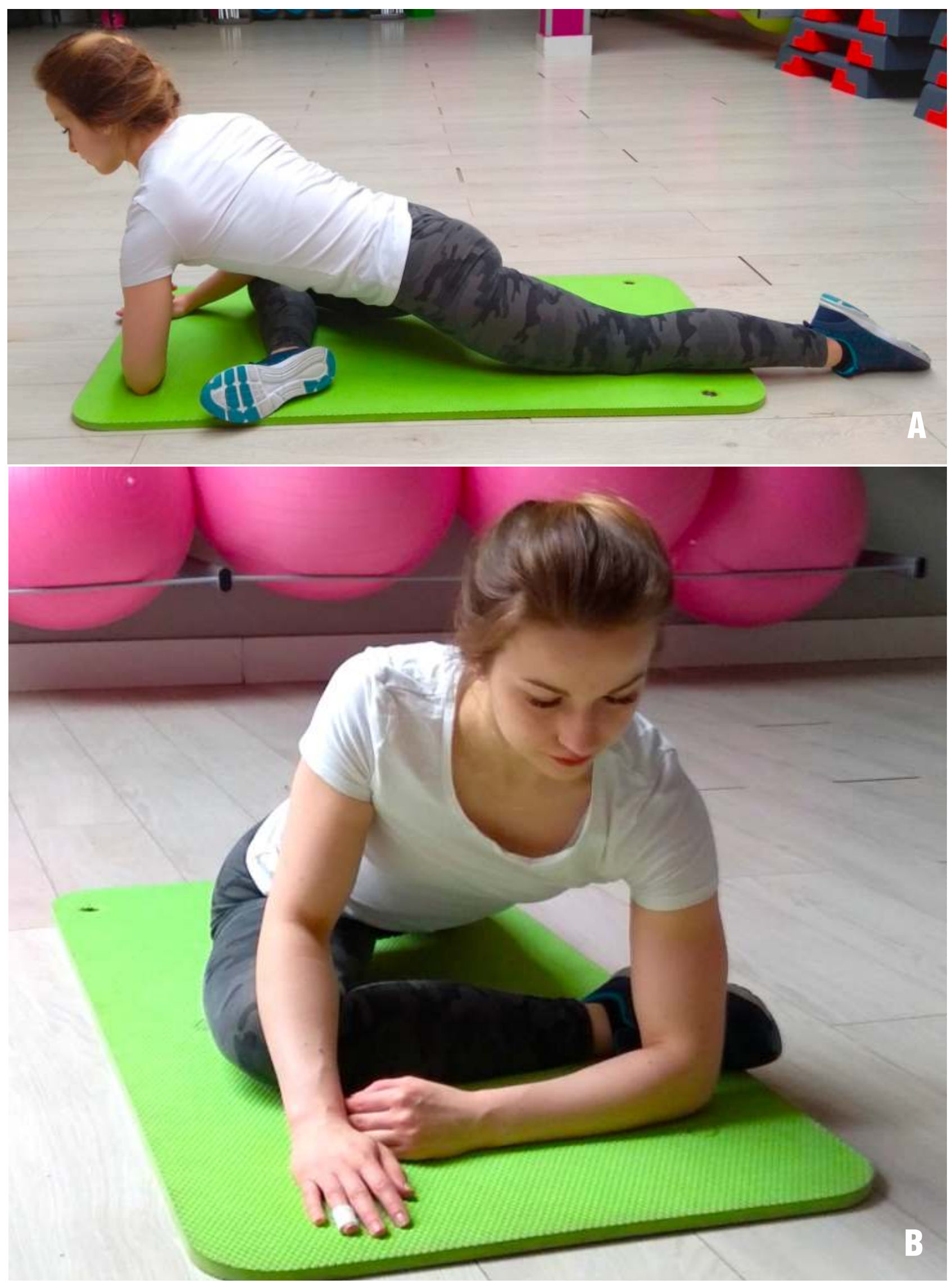

Fot. 17. Rozciąganie mięśni pośladkowych i mięśnia gruszkowatego A) z boku B) z przodu (archiwum własne, 2018) 


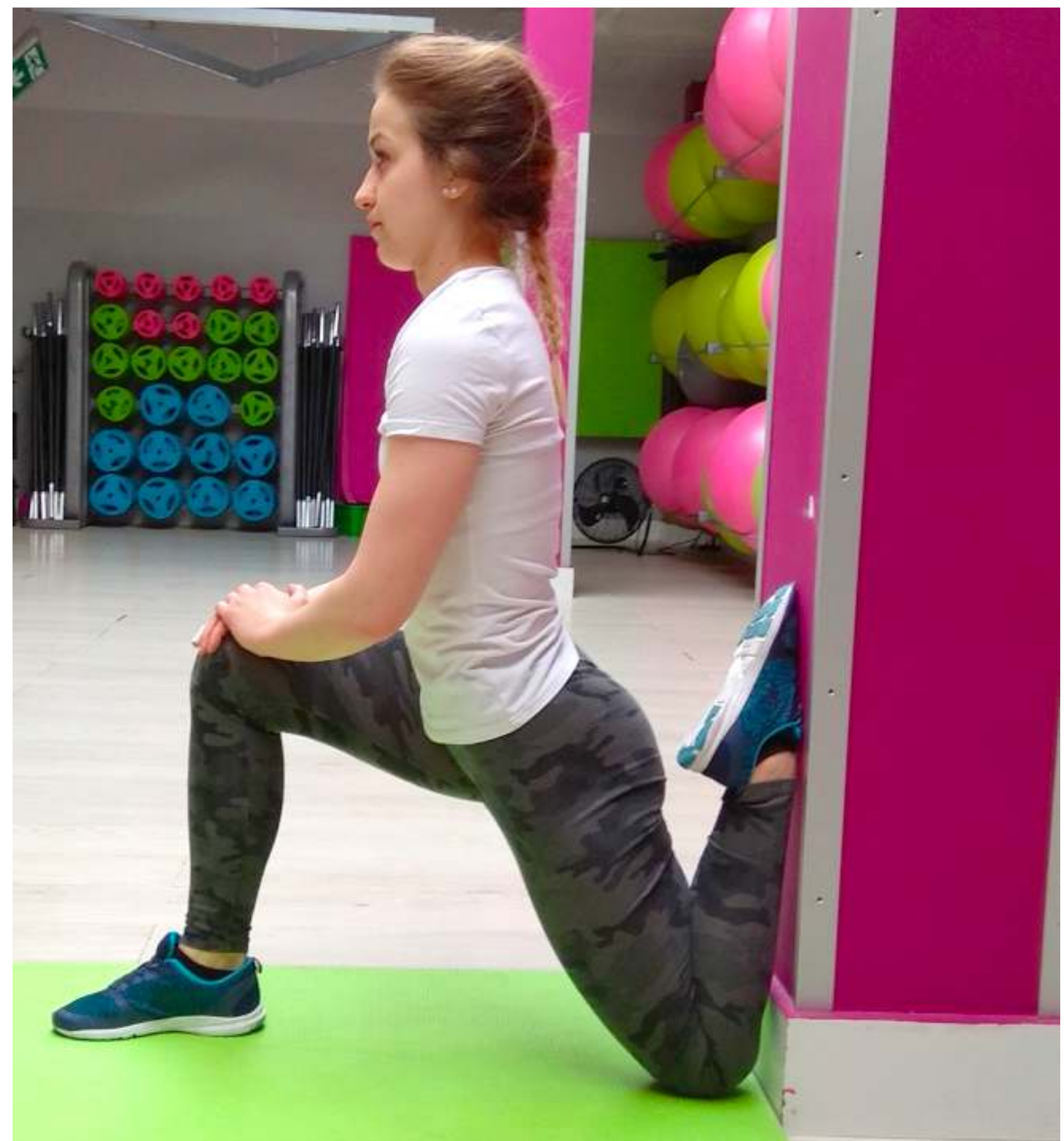

Fot. 18. Technika wykonania ćwiczenia 9 (archiwum własne, 2018)

wzmacnianie zginaczy, pozwala zmniejszyć dysbalans mięśniowy w ciele wywołany bólem, stanem zapalnym i/lub nieprawidłowym wzorcem ruchowym, bądź przyjmowaniem nieodpowiedniej postawy ciała.

Należy ustawić się tak, jak zaprezentowano na fotografii - podparcie na przedramionach, klatka piersiowa jest oparta o nogę zgiętą z przodu. Ważnym jest, aby w trakcie ruchu tułów cały czas przylegał do nogi przedniej. Nogę tylna trzyma się nad podłożem tyle, ile ćwiczący jest aktualnie w stanie utrzymać, dochodzac do przytrzymania pozycji przez około 30 sekund na stronę.

Jeżeli ćwiczący jest zdolny wykonać to zadanie ruchowe, to w późniejszym postępowaniu można dodać delikatne i z pełną kontrolą wymachy tylną nogą. W trakcie wymachu noga tylna musi być wyprostowana w stawie kolanowym i klata piersiowa przylega do nogi przedniej. Gdy noga jest u góry, to dopina się pośladek. Zalecane jest wykonanie od 8 do 15 powtórzeń na nogę. W przypadku problemów z wykonaniem tego ćwiczenia 


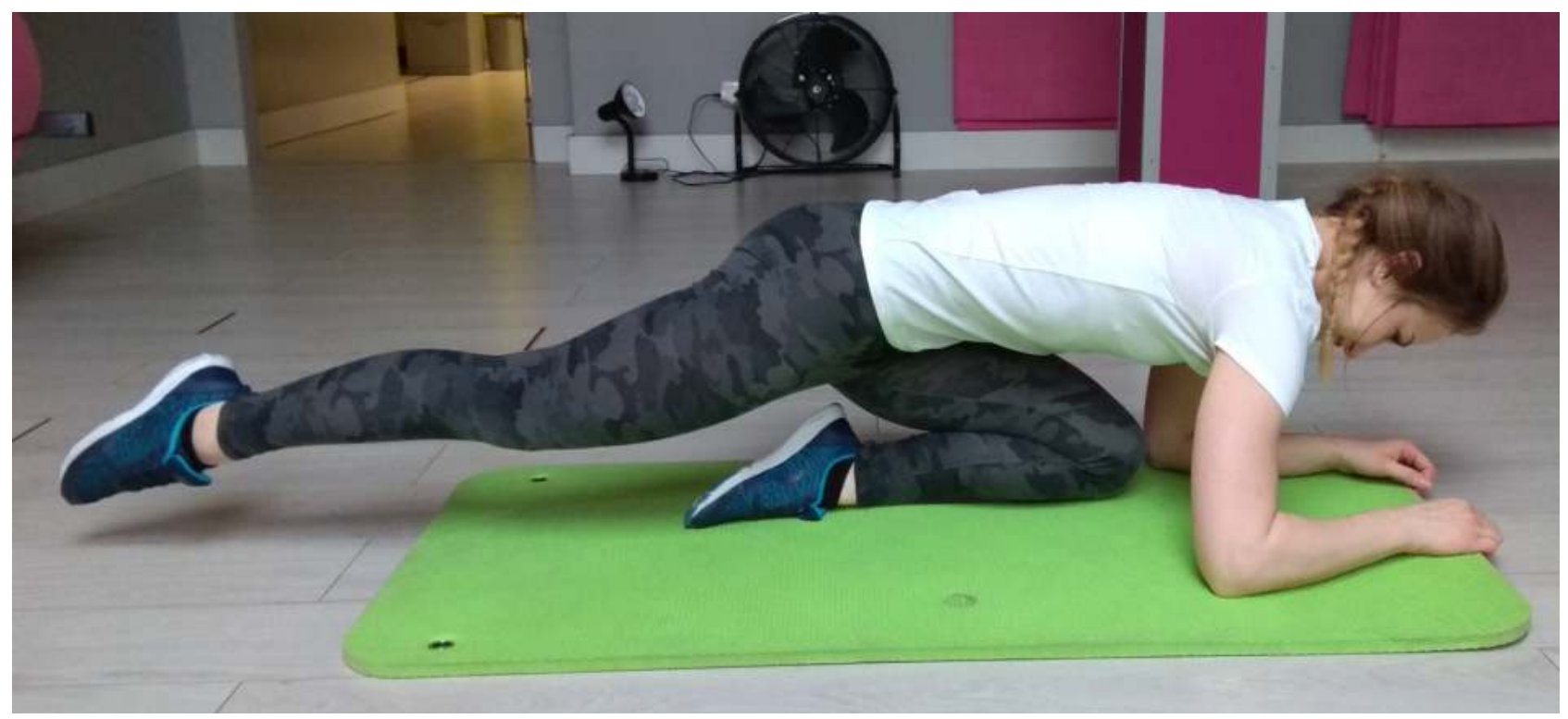

Fot. 19. Technika wykonania ćwiczenia 10 (archiwum własne, 2018)

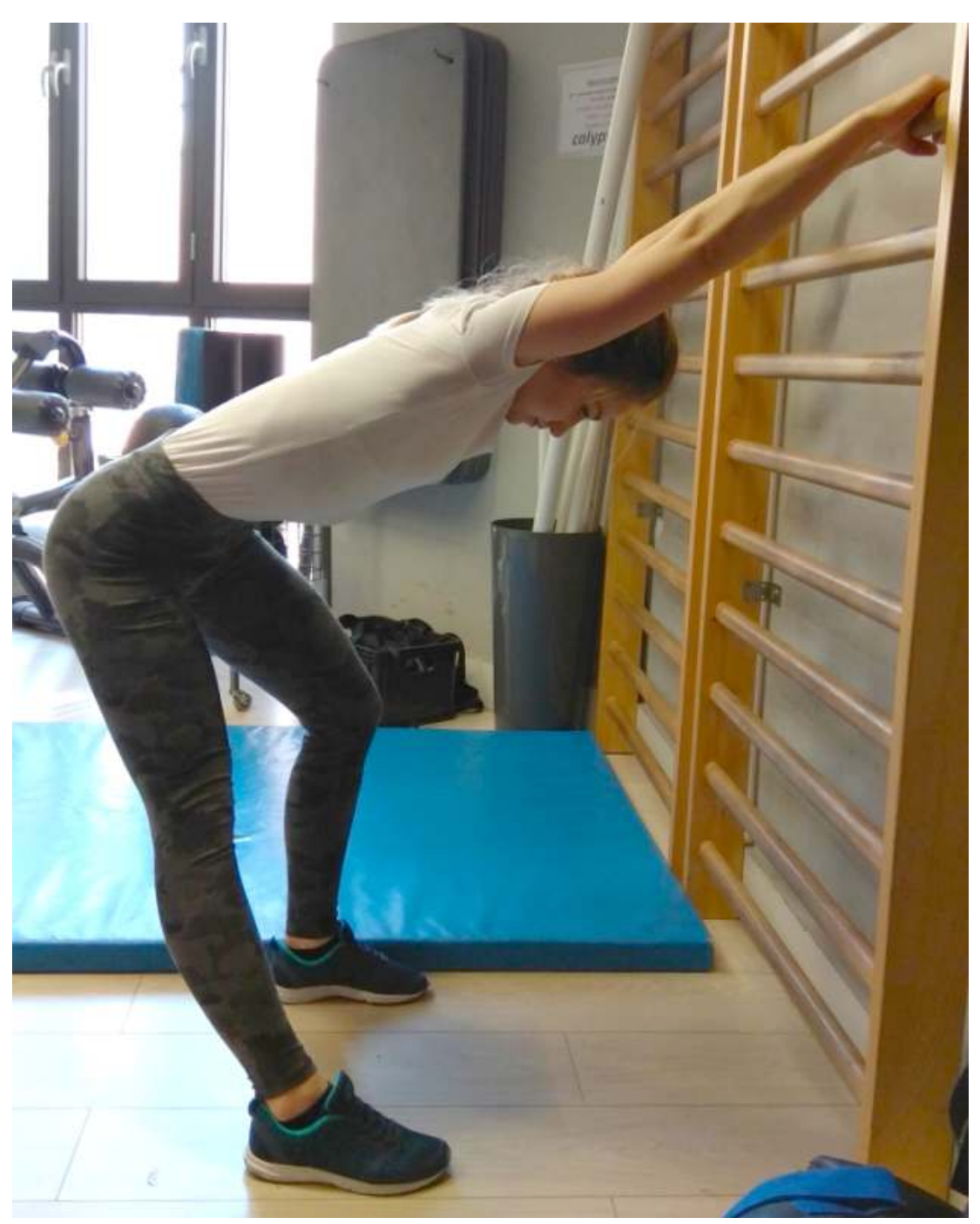

Fot. 20. Rozluźnianie i rozciąganie mięśnia najszerszego grzbietu i mięśnia czworobocznego lędźwi $z$ wykorzystaniem drabinki (archiwum własne, 2018) zaleca się kontakt z wykwalifikowanym tre-nerem, bądź fizjoterapeutą.

Ćwiczenie 11. Mięsień najszerszy grzbietu i mięsień czworoboczny lędźwi ze względu na swoje przyczepy i funkcje, jakie pełnią, wymagają także dokładnego opracowania. Jest to ważne w przypadku osób z dolegliwościami bólowymi dolnej części pleców, bądź odczuwających jakikolwiek dyskomfort z powodu siedzacego trybu życia, wykonywanej pracy zawodowej, nieprawidłowego wzorca ruchowego, nieodpowiedniej postawy ciała itp. Poniżej zostały podane dwa przykłady pozycji, które wpływają rozluźniająco i rozciągająco.

Pierwsze ćwiczenie (fot. 20) wymaga ustawienia pozycji miednicy w prawidłowy sposób, czyli pozycji przypominającej bardziej tyłopochylenie. Należy ugiąć lekko nogę przeciwną do boku, który jest rozciągany, np. jeśli wydłużany jest prawy bok, to należy delikatnie ugiać lewą nogę. Bardzo ważnym jest aby żebra „nie odstawały” - żebra muszą być „przyklejone” i napięte mięśnie brzucha. Pozycję należy trzymać od 30 sekund do 1 minuty na stronę i powtórzyć z zachowaniem prawidłowej sylwetki, w szczególności miednicy.

Pozycję pokazaną na fotografii 21 można trzymać nawet przez kilka minut w zależności od indywidualnych preferencji 

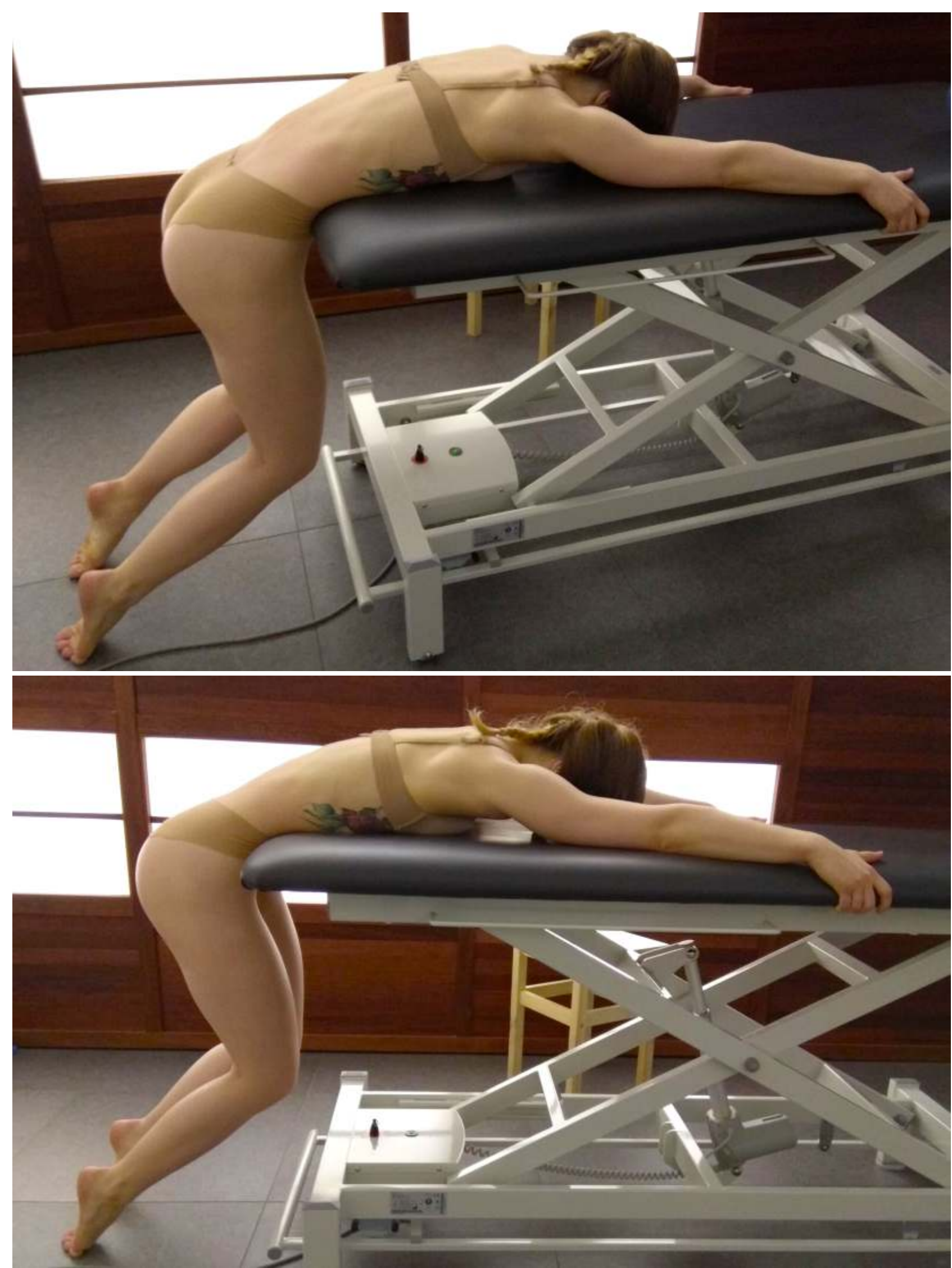

Fot. 21. Rozluźnianie i rozciąganie mięśnia najszerszego grzbietu i mięśnia czworobocznego lędźwi z wykorzystaniem łóźka ruchomego (archiwum własne, 2018) 


$$
\mathrm{Ki}^{\substack{\text { Krajowa I Ibaa } \\ \text { Fizijoterapeutow }}}
$$

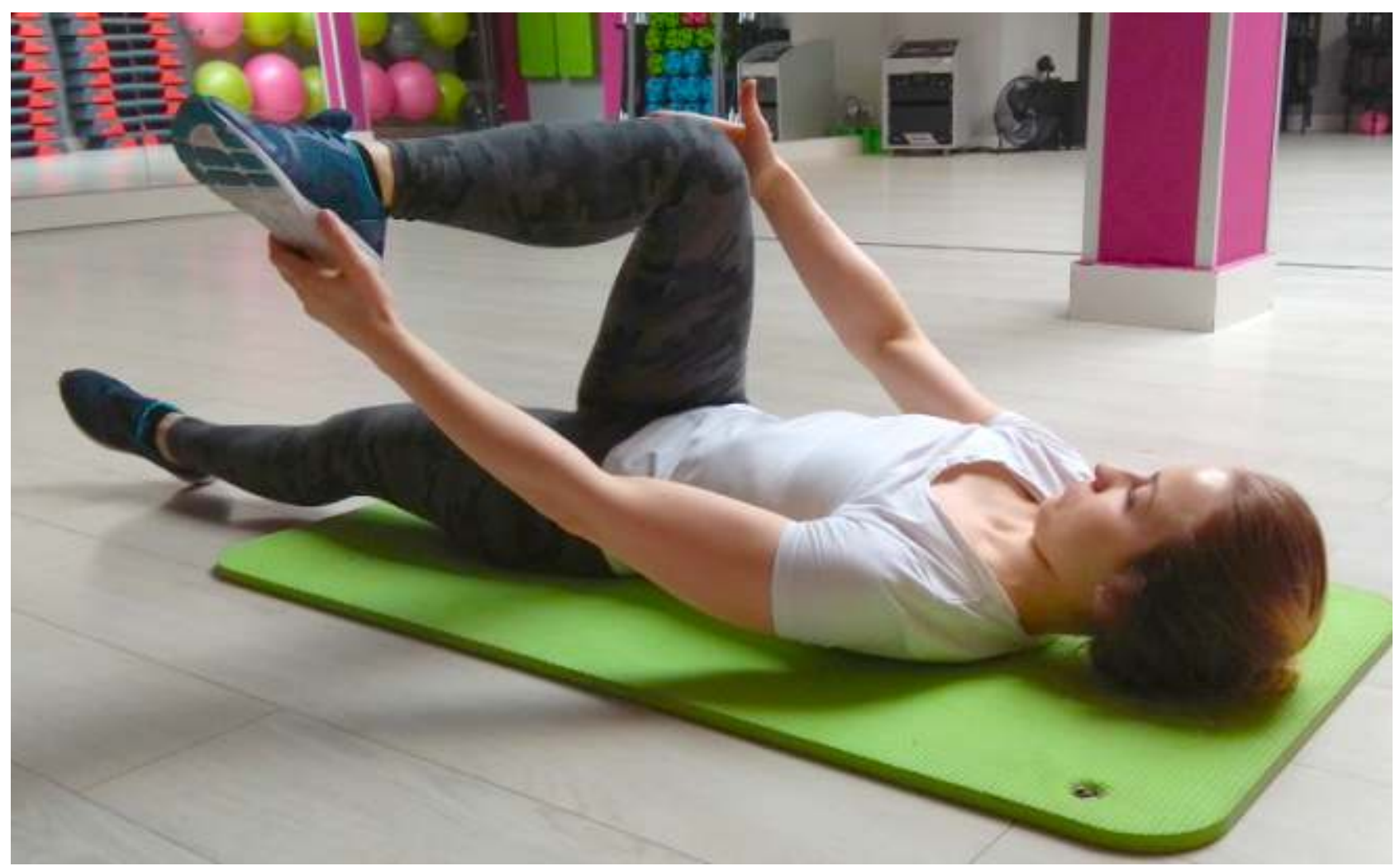

Fot. 22. Technika wykonania ćwiczenia 12 (archiwum własne, 2018)

i potrzeb. Im mocniejszy ból, tym dłużej należy przytrzymać pozycję $\mathrm{w}$ leżeniu na brzuchu, trzymając się brzegów kozetki/łóżka/box'u, ze swobodnie zwisającymi nogami.

Ćwiczenie 12. Służy rozluźnieniu mięśni obręczy kończyny dolnej i wykorzystuje poizometryczną relaksację mięśni (PIR).

Polega na tym, że pacjent przyjmuje pozycję taką, jak na fotografii 22 . Jednocześnie naciska kolanem i stopa na swoje dłonie, a dłonie przeciwdziałają temu naciskowi. Takie napięcie należy trzymać przez około 5 sekund z 3 sekundową przerwą i powtarzać od 3 do 5 razy, kilka razy dziennie. Ilość powtórzeń zależy od stanu pacjenta, zaleca się jednak, aby w zaostrzonej fazie dolegliwości wykonywać je więcej razy niż w późniejszych etapach choroby.

Podsumowanie. Autorka tego artykułu jest z wykształcenia trenerką i pracując wiele lat na siłowni, współpracując z dziećmi i innymi trenującymi. Stosując przedstawione zadania ćwiczeniowe, zauważyła wysoką skuteczność takiego działania nie tylko w odniesieniu do osób, które już doznały kontuzji, bądź borykają się z silnym bólem. Proponowane zadania ćwiczeniowe sa jak najbardziej zalecane dla osób, które w ogólne nie miały styczności z żadną aktywnością fizyczną i nie odczuwają bólu, trenują tylko hobbistycznie. Proponowane są również osobom pracującym w pozycji stojącej, siedzacej po kilka godzin dziennie, wykonującym ciężkie prace fizyczne (jak np. rozładowanie towarów), a nawet sportowcom pragnącym podnieść swoje umiejętności na wyższy poziom.

Nie oznacza to, że zaprezentowane propozycje postępowania w celu zwalczenia dolegliwości bólowych dolnej części pleców oraz poprawy aktualnych wyników sportowych i/lub polepszenia jakości sylwetki są najlepsze. Każdy może wybrać coś dla siebie. Zaletą proponowanej koncepcji jest jej uniwersalność, powszechność (dostępna dla każdego niezależnie od celu) oraz prostota. Ważne jest odpowiednie zrozumienie koncepcji, nabranie pokory, cierpliwość i determinacja, a także prawidłowe postępowanie zgodnie z zaleceniami.

Można też samemu ocenić wartość tych ćwiczeń po wykonywaniu wszystkich powyższych ćwiczeń przez około 14-30 dni, oceniając efekty, jakie odczuwa po tym czasie ćwiczacy i pamiętając, że ocena ta jest zawsze oceną subiektywną. Niewatpliwie system wymaga monitorowania jego skuteczności w odległych jednostkach czasowych. Takie też zadanie będzie przez autorke realizowane i w późniejszym okresie opisane. 